\title{
Virulence of Icelandic Pyrenophora teres f. teres populations and resistance of Icelandic spring barley lines
}

\author{
Fluturë Novakazi ${ }^{1}\left[\right.$ D $\cdot$ Magnus Göransson ${ }^{2,3}$ (1) $\cdot$ Tryggvi Sturla Stefánsson $^{4} \cdot$ Marjo Hokka $^{5} \cdot$ Marja Jalli $^{6}$. \\ Jón Hallsteinn Hallsson² ${ }^{\mathbb{B}}$
}

Received: 23 February 2021 / Accepted: 15 October 2021 / Published online: 12 November 2021

(c) The Author(s) 2021

\begin{abstract}
The causal agent of the barley net blotch disease, Pyrenophora teres, is known for its high level of diversity due to sexual reproduction. Different pathotypes, defined by a virulence combination, even within the same fields are frequently found and virulence between locations can vary considerably. Evaluation of virulence patterns of a pathogen population is essential for breeding resistant cultivars suitable for specific locations. To identify virulence patterns in Icelandic Pyrenophora teres f. teres (Ptt) isolates, twenty single spore isolates of Ptt were collected from seven locations in Iceland and analysed with AFLP markers. Principle Coordinate Analysis (PCoA) revealed Icelandic Ptt isolates clustering away from reference isolates from Austria, Finland, Sweden, Switzerland, UK, and USA. Hierarchical clustering grouped the Icelandic isolates into three distinct groups. Furthermore, the virulence of these twenty isolates was tested on 16 barley differential lines and revealed high variation in their virulence. Twenty-one barley cultivars commonly used in Iceland showed high susceptibility towards inoculation with Icelandic Ptt isolates.
\end{abstract}

Keywords Barley $\cdot$ Pyrenophora teres $\mathrm{f}$. teres $\cdot$ Pathotypes $\cdot$ Genotypes $\cdot$ Virulence

\section{Introduction}

Barley (Hordeum vulgare ssp. vulgare) is an annual cereal grain of worldwide importance, both as food and feed (Ullrich 2011). In 2017, barley ranked fourth of cereal crops for area of cultivation and quantity produced, with 47 million hectares yielding 147 million metric tons, compared

Fluturë Novakazi

fluture.novakazi@slu.se

Jón Hallsteinn Hallsson

jonhal@lbhi.is

1 Department of Plant Breeding, Swedish University of Agricultural Sciences, Alnarp, Sweden

2 Faculty of Agricultural and Environmental Sciences, Agricultural University of Iceland, Reykjavik, Iceland

3 Department of Plant Sciences, Norwegian University of Life Sciences, Ås, Norway

4 Algalif Iceland Ehf, Asbru, Iceland

5 Potato Research Institute, Ylistaro, Finland

6 Natural Resources Institute Finland (Luke), Jokioinen, Finland to 772 million metric tons of wheat (FAOSTAT 2020). In the last thirty years, barley production in Iceland has increased considerably with barley now grown on approximately 5,000 hectares (Hilmarsson et al. 2017). Several pathogenic fungal species on barley have previously been reported in Iceland (Hallgrímsson and Eyjolfsdottir 2004; Stefansson and Hallsson 2011), but only Rhynchosporium commune (syn. Rhynchosporium graminicola) has so far been suggested to be of economic importance (Hermannsson 2004). This is despite considerable fungal diversity (Stefansson and Hallsson 2011) and high levels of genetic diversity within Icelandic populations of both $R$. commune and Pyrenophora teres (Stefansson et al. 2012).

Pyrenophora teres Drechs. [anamorph Drechslera teres. (Sacc.) Shoem.] is a haploid fungus that causes barley net blotch (Mathre 1997), which is considered one of the most important diseases of barley in all major barley growing areas of the world (Mathre 1997) and causes considerable yield loss (Jalli et al. 2020; Steffenson et al. 1991). P. teres is considered one species with two forms, which are able to hybridize sexually, at least in the laboratory (Campbell and Crous 2003; Jalli 2011; Smedegard-Petersen 1978). The two differentiated forms, P. teres f. teres $(\mathrm{Ptt})$ and $P$. teres $\mathrm{f}$. 
maculata (Ptm), cause 'net type' and 'spot type' barley net blotch, respectively (Smedegaard-Petersen, 1971). P. teres isolates collected from Sardinian barley landraces clustered into two distinct groups, which corresponded to the net type and spot type of net blotch (Rau et al. 2003). No admixed genotypes were found and only a low number of markers were shared between the two groups. Consequently, the authors concluded that hybridization between the spot and net type is rare under field conditions (Rau et al. 2003). However, in populations from the Czech Republic, intermediate groups were observed also under field conditions (Leisová et al. 2005).

There are no previous reports of Ptt infecting plants in Iceland although at least twelve possible host plants exist including barley (Hordeum vulgare) (Mathre 1997), oats (Avena sativa) (Ginns 1986), rye (Secale cereale) (Richardson 1990), wheat (Triticum aestivum) (Tóth et al. 2008), common wild oat (Avena fatua), smooth brome (Bromus inermis), tufted hairgrass (Deschampsia cespitosa), foxtail barley (Hordeum jubatum), darnel ryegrass (Lolium temulentum), wavy hairgrass (Deschampsia flexuosa), red fescue (Festuca rubra), and sea/seaside barley (Hordeum marinum) (Brown et al. 1993).

Plant pathogens reproduce asexually or sexually, the latter form of reproduction leads often to a higher genetic variability (Goodwin et al. 1992). Genetic variation in Ptt populations has been reported to be generally high (Jonsson et al. 2000; Leisová et al. 2005; Peltonen et al. 1996; Rau et al. 2003; Serenius et al. 2005), with lower levels reported in Brazil (Frazzon et al. 2002). For Ptt to produce the sexual stage and overwinter in order to spread in the subsequent growing season, the fungus requires barley stubble. Therefore, the frequency of sexual reproduction depends greatly on the agronomic management (Leisová et al. 2005). Ptt is self-sterile and heterothallic, hence, two isolates with opposite mating types are necessary for sexual reproduction (McDonald 1963; Smedegard-Petersen 1978). In Finland, a ratio of 1:1 of the two mating types was observed at two locations; additionally, sexual reproduction was indicated by the lack of genetic differentiation between the isolates (Serenius et al. 2005). Ptt populations studied by Peever and Milgroom (1994) showed a multi-locus structure that suggested sexual reproduction in four out of five populations. A study on Sardinian Ptt populations genotyped with AFLP markers confirmed the high level of sexual reproduction (Rau et al. 2003). However, high genetic variability in Ptt populations can be detected even if only one of the two mating types is present. It has been suggested that this variation could be due to a large population size, retrotransposons or high mutation rates (Serenius et al. 2007).

Populations become genetically different when long distance gene flow is low (Rau et al. 2003; Serenius et al. 2005). Ptt populations from Germany, Canada, and the USA showed high levels of genetic differentiation $(\mathrm{Gst}=0.46)$ (Peever and Milgroom 1994). According to the authors, a reason for the genetic differentiation could be due to a combination of genetic drift, restricted migration and local adaptation to alternative hosts. At a smaller scale, similar levels of differentiation were found in Ptt populations from Sardinia $(F s t=0.43)$ (Rau et al. 2003).

The aim of this study was to test virulence of Icelandic strains of Ptt on spring barley lines of varying genetic background, and to screen northern European barley cultivars commonly cultivated in Iceland for resistance to Ptt.

\section{Materials and methods}

\section{Fungal isolates}

Infected leaves with visual net blotch symptoms were collected from seven locations in August 2007 (Table 1) as previously described (Stefansson et al. 2012; Stefansson and Hallsson 2011). Each leaf was placed in a paper bag, dried at room temperature for $2-3$ days and kept at $-23{ }^{\circ} \mathrm{C}$ until the leaves were sterilized in 50\% ethanol for $15 \mathrm{~s}$ and $2 \% \mathrm{NaOCl}$ for $30 \mathrm{~s}$, rinsed twice with distilled water and dried on filter paper. Sterilized leaf segments with net blotch symptoms were placed on V8 agar plates and kept at $16{ }^{\circ} \mathrm{C}$ in the dark for $48 \mathrm{~h}$ and, subsequently, at $12 \mathrm{~h}$ photoperiods for seven days. The dark parts of the mycelium were checked for conidia using a stereomicroscope $(50 \times$ magnification) and single spores were transferred onto new V8 plates using a sterile needle. The plates were kept at $16{ }^{\circ} \mathrm{C}$ under natural light for 14 days before transfer to new V8 plates for multiplication. In total, 36 single spore Ptt isolates were obtained (Table 1).

For inoculum preparation, mycelium and conidia were scraped from the agar with a microscope glass and suspended in $10 \mathrm{~mL}$ of distilled water. Conidia were counted using a hemocytometer and the concentration adjusted to $4 \times 10^{4}$ conidia $\mathrm{mL}^{-1}$.

For fungal DNA extraction, sterilized leaf segments were placed on WGA plates and incubated at $16{ }^{\circ} \mathrm{C}$ in the dark for 10-14 days. Fungal mycelium and conidia were scraped off the plates and total DNA extracted using Microbial DNA isolation Kit (MoBio, cat. No. 12224). Fungal species were identified as previously described in Stefansson and Hallsson (2011).

\section{Pyrenophora teres AFLP analysis}

The Icelandic Ptt samples were analyzed with four AFLP primer combinations (Serenius et al. 2005; Stefansson et al. 2012) with previously available data for Ptt populations from Finland, Sweden, Austria, United Kingdom, and Switzerland 
Table 1 Pyrenophora teres f. teres samples collected in Iceland for AFLP analyses and/ or virulence testing

\begin{tabular}{|c|c|c|c|c|}
\hline \multicolumn{2}{|c|}{ Isolate ID } & \multirow{2}{*}{$\begin{array}{l}\text { Sampling location } \\
\text { Kleppjárnsstaðir }\left(65^{\circ} 28^{\prime} \mathrm{N}, 14^{\circ} 25^{\prime} \mathrm{W}\right)\end{array}$} & \multirow{2}{*}{$\begin{array}{l}\text { Analysis }^{\mathrm{a}} \\
\mathrm{A}+\mathbf{V}\end{array}$} & \multirow{2}{*}{$\begin{array}{l}\text { Host cultivar } \\
\text { Unknown }\end{array}$} \\
\hline 1 & $\mathrm{KS} 2$ & & & \\
\hline 2 & KS3 & Kleppjárnsstaðir & A & Unknown \\
\hline 3 & KS6 & Kleppjárnsstaðir & A & Unknown " \\
\hline 4 & KS7 & Kleppjárnsstaðir & $A+V$ & Unknown " \\
\hline 5 & KS8 & Kleppjárnsstaðir & A & Unknown \\
\hline 6 & KS10 & Kleppjárnsstaðir & A & Unknown \\
\hline 7 & KS21 & Kleppjárnsstaðir & $A+V$ & Unknown \\
\hline 8 & KS22 & Kleppjárnsstaðir & A & Unknown \\
\hline 9 & KS23 & Kleppjárnsstaðir & A & Unknown \\
\hline 10 & KS24 & Kleppjárnsstaðir & $A+V$ & Unknown \\
\hline 11 & $\mathrm{KS} 25$ & Kleppjárnsstaðir & A & Unknown \\
\hline 12 & KS26 & Kleppjárnsstaðir & A & Unknown \\
\hline 13 & KS27 & Kleppjárnsstaðir & $A+V$ & Unknown \\
\hline 14 & KS29 & Kleppjárnsstaðir & A & Unknown \\
\hline 15 & KS30 & Kleppjárnsstaðir & A & Unknown \\
\hline 16 & KS34 & Kleppjárnsstaðir & A & Unknown \\
\hline 17 & KS35 & Kleppjárnsstaðir & $A+V$ & Unknown \\
\hline 18 & HV27 & Hvanneyri $\left(64^{\circ} 33^{\prime} \mathrm{N}, 21^{\circ} 46^{\prime} \mathrm{W}\right)$ & $\mathbf{V}$ & Olsok \\
\hline 19 & HV44 & Hvanneyri & $\mathbf{V}$ & Voitto \\
\hline 20 & HV60 & Hvanneyri & $\mathbf{V}$ & Voitto \\
\hline 21 & MO18 & Möðruvellir $\left(65^{\circ} 46^{\prime} \mathrm{N}, 18^{\circ} 15^{\prime} \mathrm{W}\right)$ & $\mathbf{V}$ & Lavrans \\
\hline 22 & MO22 & Möðruvellir & $\mathbf{V}$ & Skúmur \\
\hline 23 & MO26 & Möðruvellir & $\mathbf{V}$ & Teista \\
\hline 24 & MO57 & Möðruvellir & $\mathbf{V}$ & Tiril \\
\hline 25 & SA13 & Stóra-Ármót $\left(63^{\circ} 59^{\prime} \mathrm{N}, 20^{\circ} 56^{\circ} \mathrm{W}\right)$ & A & Filippa \\
\hline 26 & SA36 & Stóra-Ármót & $A+V$ & Filippa \\
\hline 27 & SA47 & Stóra-Ármót & $A+\mathbf{V}$ & Filippa \\
\hline 28 & SA54 & Stóra-Ármót & $A+V$ & Filippa \\
\hline 29 & SA56 & Stóra-Ármót & $A+V$ & Filippa \\
\hline 30 & VH14 & Vindheimar $\left(65^{\circ} 30^{\prime} \mathrm{N}, 19^{\circ} 21^{\prime} \mathrm{W}\right)$ & A & Skúmur II \\
\hline 31 & VH34 & Vindheimar & $\mathbf{V}$ & Voitto \\
\hline 32 & VH44 & Vindheimar & A & Skúmur II \\
\hline 33 & VH57 & Vindheimar & A & Judit \\
\hline 34 & SB7 & Refsmýri $\left(65^{\circ} 14^{\prime} \mathrm{N}, 14^{\circ} 35^{\prime} \mathrm{W}\right)$ & $\mathbf{V}$ & Unknown \\
\hline 35 & SB8 & Hlaðir $\left(65^{\circ} 46^{\prime} \mathrm{N}, 18^{\circ} 11^{\prime} \mathrm{W}\right)$ & A & Unknown \\
\hline 36 & SB10 & Vallanes $\left(65^{\circ} 11^{\prime} \mathrm{N}, 14^{\circ} 32^{\prime} \mathrm{W}\right)$ & $\mathbf{V}$ & Unknown \\
\hline
\end{tabular}

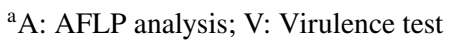

for comparison. Restriction, ligation and PCR amplification was as previously described (Serenius et al. 2005; Stefansson et al. 2012). Genetic distances between isolates were calculated using GenAlEx 6.5 (Peakall and Smouse 2006, 2012) using the 'Binary-Haploid' option under 'Genetic Distance'. A Principal Coordinates Analysis (PCoA) was used to visualize the results using the 'Covariance-Standardized' option.

\section{Plant material and greenhouse trials}

Twenty single spore isolates were tested for virulence on 16 barley differential lines (Table 2). Two seeds per genotype were sown together, with eight or nine genotypes per pot in two replications. Seeds were sown in nutrient supplemented peat and pots placed in the greenhouse at $18-20{ }^{\circ} \mathrm{C}$ during the day and $15{ }^{\circ} \mathrm{C}$ during the night with $16 \mathrm{~h} / 8 \mathrm{~h}$ photoperiods. Two weeks after sowing, at the 2-3 leaf stage, relative humidity was raised to $100 \%$ and plants were inoculated by spray inoculation with a homogenized conidial suspension using $0.4 \mathrm{~mL}$ per genotype and $3.2 \mathrm{~mL}$ per pot. A set of differential lines treated with pure water was included in the trial. Leaf symptoms were scored on the second leaf ten days after inoculation using the Tekauz scale of 1-10 (Tekauz 1985). The Tekauz scale assesses the infection response type 
Table 2 Differential barley genotypes for Pyrenophora teres f. teres and known resistance types

\begin{tabular}{lll}
\hline Genotype (accession no-origin) & Resistance type & Reference \\
\hline Canadian Lake Shore (CI 2750_USA) & Pt2, Pt3 & (Fowler et al. 2017; Mode and Schaller 1958) \\
Harbin (CI 4929, Manchuria) & Pt2 & (Mode and Schaller 1958) \\
k-8755 (Ethiopia) & 1 & (Afanasenko et al. 2007) \\
k-20019 (Ethiopia) & $2-4$ & (Afanasenko et al. 1999) \\
Manchurian (CI 739) & Pt2 & (Richter et al. 1998) \\
Tifang (CI 4407-1, USA) & Pt1, Rpt1a & (Bockelmann et al. 1977; O'Boyle 2009; Schaller 1955) \\
CI 9825 (Ethiopia) & $1-4$ & (Afanasenko et al. 1999; Khan and Boyd 1969) \\
CI 5791 (Ethiopia) & 13 & (Afanasenko et al. 1999; Khan and Boyd 1969; Selim et al. 1973) \\
Manchuria (CI 2330) & & \\
Beecher (USA) & 1 & (Fowler et al. 2017; Selim et al. 1973) \\
CI 9214 (Korea) & & \\
Skiff (Australia) & & (Fowler et al. 2017) \\
CI 11,458 (Poland) & & (Fowler et al. 2017) \\
Prior (Australia) & & (Afanasenko et al. 2015) \\
Corvette (Australia) &
\end{tabular}

(IRT). In this scale, 1 indicates a resistant reaction and 10 a susceptible one. A resistant reaction is defined by small pinpoint lesions and a susceptible reaction by large chlorotic regions with necrotic margins that have merged into each other. Generally, IRT from 1-3 are considered resistant, 4-5 as moderately resistant, 6-7 as moderately susceptible, and 8-10 as susceptible. Dendrograms showing the clustering of both barley varieties and fungal isolates were rendered in ClustVis (Metsalu and Vilo 2015) using Euclidean distance and average linkage.

In addition, 21 northern European cultivars used in Iceland (four from Sweden and Finland, five from Norway, and eight from Iceland) (Table 3), were screened under greenhouse conditions with an equal mixture of the Icelandic Ptt isolates previously used for virulence testing. Genotypes were sown in a complete randomized block design with two seeds per pot in three replications. Greenhouse conditions, inoculation, and screening procedures were as described above.

\section{Results}

\section{Population structure and virulence of Icelandic Pyrenophora teres isolates}

Hierarchical clustering separated the isolates into three distinct groups (Fig. 1). The first group (blue) consisted of eleven isolates from three locations. Six isolates were from Kleppjárnsstaðir, four from Stóra-Ármót, and one from Vallanes. Group two (red) comprised two isolates, one from Refsmýri, and one from Möðruvellir. Group three (green) comprised seven isolates from three regions, Möðruvellir, Hvanneyri, and Vindheimar. Overall, group one was the least virulent with a mean score of 4.3 across all barley differentials and all eleven isolates belonging to this group (Fig. 1). Groups two and three showed mean virulence scores of 4.7 and 5.1, respectively.

Table 3 Reaction of Scandinavian barley cultivars to Pyrenophora teres $\mathrm{f}$. teres isolates from Iceland

\begin{tabular}{|c|c|c|c|c|}
\hline Variety & Origin & Row type & Mean & Phenotype \\
\hline Tiril & Norway & 6 & 9 & $\mathrm{~S}$ \\
\hline Ven & Norway & 6 & 9 & $\mathrm{~S}$ \\
\hline Arve & Norway & 6 & 9 & $\mathrm{~S}$ \\
\hline Lavrans & Norway & 6 & 8 & $\mathrm{~S}$ \\
\hline Olsok & Norway & 6 & 8 & $\mathrm{~S}$ \\
\hline Judit & Sweden & 6 & 9 & $\mathrm{~S}$ \\
\hline Filippa & Sweden & 2 & 8 & $\mathrm{~S}$ \\
\hline Rekyl & Sweden & 2 & 8 & $\mathrm{~S}$ \\
\hline Barbro & Sweden & 2 & 7 & MS \\
\hline Erkki & Finland & 6 & 8 & $\mathrm{~S}$ \\
\hline Kunnari & Finland & 6 & 7 & MS \\
\hline Rolfi & Finland & 6 & 8 & $\mathrm{~S}$ \\
\hline Saana & Finland & 2 & 6 & MR-MS \\
\hline $246-12$ & Iceland & 6 & 9 & $\mathrm{~S}$ \\
\hline $247-1$ & Iceland & 6 & 9 & $\mathrm{~S}$ \\
\hline $248-1$ & Iceland & 6 & 9 & $\mathrm{~S}$ \\
\hline Kría & Iceland & 2 & 8 & $\mathrm{~S}$ \\
\hline Skegla & Iceland & 2 & 8 & $\mathrm{~S}$ \\
\hline Skúmur & Iceland & 6 & 8 & $\mathrm{~S}$ \\
\hline Lómur & Iceland & 6 & 8 & $\mathrm{~S}$ \\
\hline Teista & Iceland & 2 & 7 & MS \\
\hline
\end{tabular}

S: susceptible; MS: moderately susceptible; MR: moderately resistant 
Isolates of group one were less virulent on cultivar 'Tifang' with a mean virulence score of 2.7 , compared to mean scores of 5.5 and 6.1 of groups two and three, respectively. Group two was least virulent on cultivar 'Pirkka' with a mean score of 3.0 compared to 7.7 and 7.5 of groups one and three, respectively. Finally, group three was slightly less virulent on line 'CI 5791' with a mean virulence score of 1.9 compared to 2.3 of groups one and two.

For the Principal Coordinates Analysis (PCoA), coordinates 1 and 2 explained 51.9 and $11.0 \%$ of the observed genetic distance, respectively (Fig. 2). The samples showed clear geographical differences with the Finnish isolates forming a compact cluster, and the Icelandic isolates mostly clustering together, although not as tightly as the Finnish isolates.

Twenty Ptt isolates were tested for virulence in a set of 16 barley differential lines (Fig. 1). Average virulence scores ranged from $2.0-8.6$ among the 20 isolates, with an overall mean of 4.6. The raw scoring data can be found in Supplementary Table 1. All isolates were both virulent and non-virulent among the 16 barley differential lines tested. The least virulent isolate was SA56 with an average score of 3.3, and the most virulent isolate was VH35 with an average score of 5.8.

There was variation among the 16 barley differential lines for susceptibility towards the Icelandic Ptt population. CI 5791 was resistant, and Corvette was susceptible to all isolates. The average virulence score ranged from 2.2 to 8.4 for CI 5791 and Corvette, respectively (Fig. 1). Genotypes with an average scoring $<4$ were considered resistant. Five genotypes had an average scoring $<4$ and were thus deemed resistant (CI 5791, CI 9825, K 20,019, CI 9214, and CI $11,458)$. Three of the five resistant genotypes carried previously reported Ptt resistance genes (Table 2).

\section{Reaction of northern European barley cultivars to Icelandic Pyrenophora teres isolates}

Analysis of the net blotch resistance of 21 northern European and Icelandic barley cultivars, representing the most frequently used cultivars in Iceland, was assessed using a mixture of Ptt isolates from Iceland. Seventeen cultivars were rated as susceptible (S), 'Kunnari' from Finland, 'Teista' from Iceland, and 'Barbro' from Sweden were considered moderately susceptible (MS), and 'Saana' from Finland was moderately resistant/moderately susceptible (MR-MS) with a mean virulence score of 6 (Table 3 ).

\section{Discussion}

The 16 barley genotypes used for differentiating Icelandic $P$. teres isolates showed a high variation in their reactions towards inoculation with Ptt. Most of these differential lines have been used in previous studies. Afanasenko et al. (2009) tested $1059 \mathrm{Ptt}$ isolates from different European countries on 14 barley genotypes, 13 of which overlap with the differentials used here. In their study, 'Pirkka' was the most susceptible (S) genotype with disease severities of $90-100 \%$. This matches the results in the present study, where 'Pirkka' was mostly S to the used isolates. Genotypes 'Skiff', 'Prior', and 'CI 2750' were moderately susceptible (MS) to S reactions in both studies, and genotype 'CI 5791' was the most resistant (R) line. 'Manchurian' and 'Beecher' exhibited moderately resistant (MR) to MS reactions in the present study and the study by Afanasenko et al. (2009). 'K 20,019', 'CI 9825', and 'CI 9214' were R to MR towards Icelandic isolates, but were MS towards the European set of Ptt isolates tested by Afanasenko et al. (2009). 'Tifang' and ' $\mathrm{K} 8755$ ' expressed disease severities between $0-75 \%$ and $0-36 \%$ in the study (Afanasenko et al. 2009), respectively, but showed R to MS reactions towards Icelandic isolates. Lastly, 'Harbin' showed disease severities of 0-64\% towards the European set and exhibited MR to $\mathrm{S}$ reactions towards the Icelandic isolates. Genotype 'Corvette' was the most S line tested here and was also mostly $\mathrm{S}$ in a study by Fowler et al. (2017), who screened 123 Australian isolates on 31 barley genotypes. Genotypes 'CI 2750', 'Beecher', and 'Harbin' were mostly $\mathrm{R}$ in the study by Fowler et al. (2017), but showed MR to $\mathrm{S}$ reactions in the present study. 'Skiff' and 'Prior' were $\mathrm{S}$ towards 50 and $30 \%$ of the Australian isolates, respectively, but MS to $\mathrm{S}$ towards the Icelandic isolates. Finally, 'CI 11,458' and 'CI 5791' were MR and R to the Australian and Icelandic isolates. Koladia et al. (2017) tested nine geographically diverse isolates on 117 barley RILs of a cross between 'CI 5791 and 'Tifang'. They showed that 'Tifang' was resistant towards four out of nine isolates, which corresponds well with the present study, where 'Tifang' was R to half of the isolates. 'CI 5791' was highly R to all isolates used by Koladia et al. (2017) and all the Icelandic isolates. Novakazi et al. (2019) tested isolates from Russia, Germany, and Australia in greenhouse trials for seedling resistance and in field trials for adult plant resistance and found genotypes 'K 8755', 'K 20,019', 'Harbin', 'CI 9825', and 'CI 5791' to show $\mathrm{R}$ in all the experiments. Genotypes 'CI 9825' and 'CI 5791' were also R to all Icelandic isolates; however, genotypes 'K 8755', 'K 20,019', and 'Harbin' exhibited differential reactions to the Icelandic isolates. 'Prior' has mostly proven to be $\mathrm{R}$ in field trials, but $\mathrm{S}$ in seedling trials and towards the Icelandic isolates. 'Corvette' has mostly proven to be MR, except in field trials with isolate 'NFNB 85' but was the most $\mathrm{S}$ genotype in the present study. 'Skiff' exhibited $\mathrm{R}$ to $\mathrm{S}$ reactions depending on the isolate and location, which was also shown by Wallwork et al. (2016), but was generally moderately susceptible in the present study.

Hierarchical clustering grouped the $20 \mathrm{Ptt}$ isolates into three groups. Isolates belonging to group 1 were collected in the West (Stóra-Ármót) and the East (Kleppjárnstaðir 

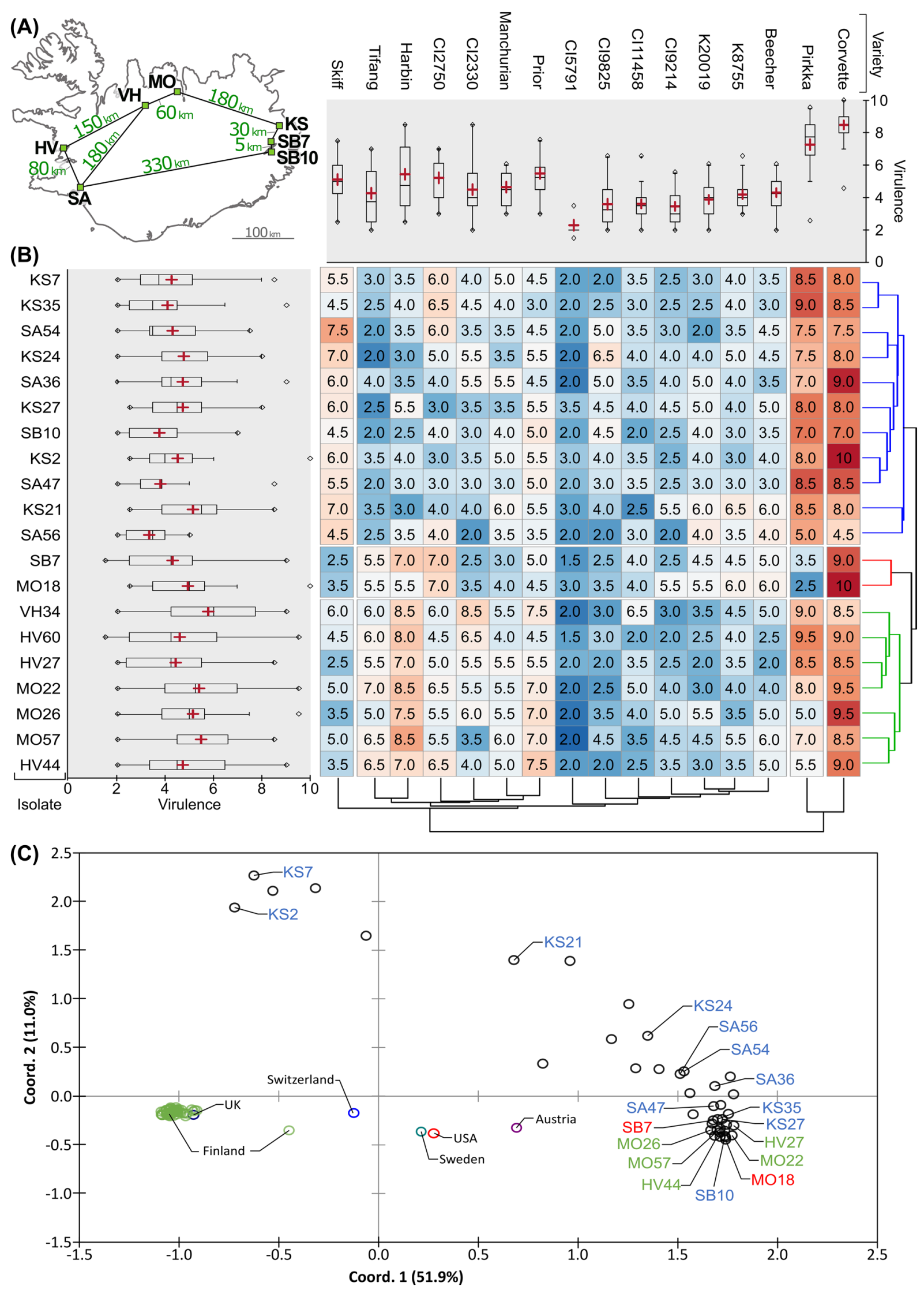
४Fig. 1 (A) Map of Iceland showing distances, in kilometers, between sampling locations. (B) Heat map showing the virulence of 20 Icelandic Pyrenophora teres f. teres isolates on 16 barley differential lines after seedling inoculation, with hierarchical cluster dendrograms for both varieties and fungal isolates and boxplots showing the distribution of data. (C) Principal Coordinate Analysis (PCoA) of Pyrenophora teres $\mathrm{f}$. teres isolates based on AFLP marker analysis. Color coding of Icelandic samples as in Fig. 1, based on hierarchical clustering

and Vallanes). Group 2 comprised one isolate each from the North (Möðruvellir) and the East (Refsmýri), and group 3 comprised isolates from the North (Möðruvellir and Vindheimar) and the West (Hvanneyri). Among the 20 isolates 19 pathotypes were identified. Isolates SA54 and KS7 belonged to the same pathotype and were both found in group 1. A pathotype is defined as a group of genotypes within a pathogen species that is distinguished by its virulence spectrum (Niks et al. 2011). Pathotype diversity has been described in several studies from different countries. Among $180 \mathrm{Ptt}$ isolates from Western Canada 45 pathotypes were identified (Tekauz 1990). In Ptt populations from California and North Dakota, 13 and 45 pathotypes among 91 and 75 isolates were described, respectively (Liu et al. 2012; Steffenson and Webster 1992). Oğuz and Karakaya (2017) identified 24 pathotypes among 40 Turkish Ptt isolates, Bouajila et al. (2011) identified 20 pathotypes among 104 isolates from Syria and Tunisia, and Boungab et al. (2012) found 12 pathotypes among 48 Algerian isolates. Jonsson et al. (1997) tested 24 Swedish and two Canadian isolates and found 14 pathotypes. In a study by Afanasenko et al. (2009) a set of more than 1,000 isolates from Russia, Europe, Australia, and Canada were tested on 17 barley genotypes. Depending on the number of barley differentials and the sub-set of isolates used, the number of pathotypes was between two and 216. Within the 20 analyzed isolates in the present study, 19 pathotypes were identified. With the results of previous studies in mind, a higher number of isolates would most likely identify more than 19 pathotypes within the Icelandic $P$. teres populations. To estimate the magnitude of number of pathotypes is difficult. However, further studies with about 100 isolates could give a better overview about the pathotype diversity within Icelandic $P$. teres isolates.

Our results show that the previously described genetic diversity found within the Icelandic $P$. teres population (Stefansson et al. 2012) is not only neutral differences in genetic markers but that it translates into differences in virulence, and that most of the popular Icelandic barley varieties are susceptible to the isolates. With increased barley cultivation in Iceland, which most likely will mean higher disease loads in farmers' fields, it is therefore of importance to factor disease resistance into Icelandic barley breeding projects. Our results also show that despite geographical isolation and a relatively short period of continuous barley cultivation Iceland harbors surprising diversity in pathotypes.

Supplementary information The online version contains supplementary material available at https://doi.org/10.1007/s42161-021-00972-5.

Acknowledgements The authors would like to thank farmers around Iceland for assistance with sample collection. We would also like to thank the Icelandic Agricultural Productivity Fund for funding.

Funding Open access funding provided by Swedish University of Agricultural Sciences. The study was partly funded by the Icelandic Agricultural Productivity Fund.

Availability of data and material The datasets generated during and/or analyzed during the current study are available from the corresponding author on reasonable request.

\section{Declarations}

Ethics approval Not applicable.

Consent to participate Not applicable.

Consent for publication Not applicable.

Conflict of interest The authors declare no conflict of interest.

Open Access This article is licensed under a Creative Commons Attribution 4.0 International License, which permits use, sharing, adaptation, distribution and reproduction in any medium or format, as long as you give appropriate credit to the original author(s) and the source, provide a link to the Creative Commons licence, and indicate if changes were made. The images or other third party material in this article are included in the article's Creative Commons licence, unless indicated otherwise in a credit line to the material. If material is not included in the article's Creative Commons licence and your intended use is not permitted by statutory regulation or exceeds the permitted use, you will need to obtain permission directly from the copyright holder. To view a copy of this licence, visit http://creativecommons.org/licenses/by/4.0/.

\section{References}

Afanasenko OS, Jalli M, Pinnschmidt HO, Filatova O, Platz GJ (2009) Development of an international standard set of barley differential genotypes for Pyrenophora teres f. teres. Plant Pathol 58(4):665676. https://doi.org/10.1111/j.1365-3059.2009.02062.x

Afanasenko OS, Koziakov AV, Hedlay PE, Lashina NM, Anisimova AV, Manninen O, Jalli M, Potokina EK (2015) Mapping of the loci controlling the resistance to Pyrenophora teres f. teres and Cochliobolus sativus in two double haploid barley populations. Russ J Genet: App Res 5(3):242-253. https://doi.org/10.1134/ s2079059715030028

Afanasenko OS, Makarova I, Zubkovich A (1999) The number of genes controlling resistance to Pyrenophora teres drechs. strains in barley. Russ J Genet 35:274-283

Afanasenko O, Mironenko N, Filatova O, Kopahnke D, Krämer I, Ordon F (2007) Genetics of host-pathogen interactions in the 
Pyrenophora teres f. teres (net form) - Barley (Hordeum vulgare) pathosystem. Europ J Plant Pathol 117(3):267-280. https://doi. org/10.1007/s10658-006-9093-5

Bockelmann HE, Sharp EL, Eslick RF (1977) Trisomic analysis of genes for resistance to scald and net blotch in several barley cultivars. Can J Bot 55(15):2142-2148. https://doi.org/10.1139/ b77-242

Bouajila A, Zoghlami N, Al Ahmed M, Baum M, Ghorbel A, Nazari K (2011) Comparative virulence of Pyrenophora teres $\mathrm{f}$. teres from Syria and Tunisia and screening for resistance sources in barley: Implications for breeding. Lett App Microbiol 53(5):489502. https://doi.org/10.1111/j.1472-765X.2011.03127.x

Boungab K, Belabid L, Fortas Z, Bayaa B (2012) Pathotype diversity among Algerian isolates of Pyrenophora teres f. teres. Phytopathol Mediterranea 51(3):577-586

Brown MP, Steffenson BJ, Webster RK (1993) Host range of Pyrenophora teres $\mathrm{f}$. teres isolates from California. Plant Disease 77(9):942-947

Campbell GF, Crous PW (2003) Genetic stability of net $\times$ spot hybrid progeny of the barley pathogen Pyrenophora teres. Australas Plant Pathol 2(32):283-287. https://doi.org/10.1071/AP03016

FAOSTAT (2020) http://www.fao.org/faostat/en/\#home. http://www. fao.org/faostat/en/\#home

Fowler RA, Platz GJ, Bell KL, Fletcher SEH, Franckowiak JD, Hickey LT (2017) Pathogenic variation of Pyrenophora teres $\mathrm{f}$. teres in Australia. Austra Plant Pathol 46(2):115-128. https://doi.org/10. 1007/s13313-017-0468-1

Frazzon APG, Matsumura ATS, Van Der Sand ST (2002) Morphological characterization and genetic analysis of Drechslera teres isolates. Genet Mol Biol 25(2):235-241. https://doi.org/10.1590/ S1415-47572002000200019

Ginns JH (1986) Compendium of Plant Disease and Decay Fungi in Canada1960-1980. Ottawa, Ontario: Biosystemat Res Centre

Goodwin SB, Spielman LJ, Matuszak JM, Bergeron SN, Fry WE (1992) Clonal Diversity and Genetic Differentiation of Phytophthora infestans Populations in Northern and Central Mexico. Phytopathology 82(9):955-961

Hallgrímsson H, Eyjolfsdottir G (2004) Íslenskt sveppatal. Checklist of Icelandic fungi. 1, Microfungi. IINH 45. https://rafhladan.is/ handle/10802/4090. Accessed 19 June 2019

Hermannsson J (2004) Bygg í sáðskiptum (in Icelandic). In Frceðaping Landbúnaðarins (pp. 178-184). Reykjavik, Iceland: BÍ/LbhÍ. https://www.google.de/search? biw $=1366 \&$ bih $=625 \& \mathrm{ei}=$ g5AUXaPGAqTprgTu26CICg\&q=Hermannsson $\% 252 \mathrm{C}+\mathrm{J} .+\%$ $25282004 \% 2529 .+\mathrm{Sj} \% 25 \mathrm{C} 3 \% 25 \mathrm{BAkd} \% 25 \mathrm{C} 3 \% 25 \mathrm{~B} 3 \mathrm{mar}+\% 25 \mathrm{C} 3 \%$ $25 \mathrm{AD}+$ byggi+\% $2528 \mathrm{in}+$ Icelandic $\% 2529 .+\mathrm{Fr} \% 25 \mathrm{C} 3 \% 25 \mathrm{~A} 6 \%$ 25C3\%25B0a\%25C3\%25BEing+Landb\%25C3\%25BAna\%25C3\% 25B0arins\%252C+B. Accessed 27 June 2019

Hilmarsson HS, Göransson M, Lillemo M, Kristjánsdóttir PA, Hermannsson J, Hallsson JH (2017) An overview of barley breeding and variety trials in Iceland in 1987-2014. Iceland Agricul Sci 30:13-28. https://doi.org/10.16886/ias.2017.02

Jalli M (2011) Sexual reproduction and soil tillage effects on virulence of Pyrenophora teres in Finland. Ann App Biol 158(1):95-105. https://doi.org/10.1111/j.1744-7348.2010.00445.x

Jalli M, Kaseva J, Andersson B, Ficke A, Nistrup-Jørgensen L, Ronis A et al (2020) Yield increases due to fungicide control of leaf blotch diseases in wheat and barley as a basis for IPM decision-making in the Nordic-Baltic region. Eur J Plant Pathol 158(2):315-333. https://doi.org/10.1007/s10658-020-02075-w

Jonsson R, Bryngelsson T, Gustafsson M (1997) Virulence studies of Swedish net blotch isolates (Drechslera teres) and identification of resistant barley lines. Euphytica 94(2):209-218. https://doi.org/ 10.1023/A: 1002924424200
Jonsson R, Säil T, Bryngelsson T (2000) Genetic diversity for random amplified polymorphic DNA (RAPD) markers in two Swedish populations of Pyrenophora teres. Can J Plant Path 22(3):258 264. https://doi.org/10.1080/07060660009500473

Khan TN, Boyd WJ (1969) Inheritance of Resistance to Net Blotch in Barley. Ii. Genes Conditioning Resistance Against Race W.a.2. Canad J Genet Cytol 11(3):592-597. https://doi.org/10.1139/ g69-069

Koladia VM, Faris JD, Richards JK, Brueggeman RS, Chao S, Friesen TL (2017) Genetic analysis of net form net blotch resistance in barley lines CIho 5791 and Tifang against a global collection of P. teres f. teres isolates. Theoret App Genet 130(1):163-173. https:// doi.org/10.1007/s00122-016-2801-4

Leisová L, Hanzalová A, Kucera L (2005) Genetic diversity of Pyrenophora teres isolates as detected by AFLP analysis. J Plant Pathol 90(2):233-245

Liu ZH, Zhong S, Stasko AK, Edwards MC, Friesen TL (2012) Virulence Profile and Genetic Structure of a North Dakota Population of Pyrenophora teres f. teres, the Causal Agent of Net Form Net Blotch of Barley. Phytopathol 102(5):539-546. https://doi.org/ 10.1094/phyto-09-11-0243

Mathre D (1997) Compendium of Barley Diseases, 2nd edn. American Phytopathological Society, Minnesota

McDonald W (1963) Heterothallism in Pyrenophora teres. Phytopathology 53:771-773

Metsalu T, Vilo J (2015) ClustVis: a web tool for visualizing clustering of multivariate data using Principal Component Analysis and heatmap. Nucleic Acids Res 43(W1):W566-W570. https://doi. org/10.1093/nar/gkv468

Mode CJ, Schaller CW (1958) Two Additional Factors for Host Resistance to Net Blotch in Barley. Agron J 50(1):15-18. https://doi.org/ 10.2134/agronj1958.00021962005000010005x

Niks RE, Parlevliet JE, Lindhout P, Bai Y (2011) Breeding Crops with Resistance to Diseases and Pests. (R. E. Niks, J. E. Parlevliet, P. Lindhout, \& Y. Bai, Eds.). Waginingen, Netherlands: Wageningen Academic Publishers

Novakazi F, Afanasenko OS, Anisimova A, Platz GJ, Snowdon R, Kovaleva $\mathrm{O}$ et al (2019) Genetic analysis of a worldwide barley collection for resistance to net form of net blotch disease (Pyrenophora teres $\mathrm{f}$. teres). Theoreti App Genet. https://doi.org/10. 1007/s00122-019-03378-1

O’Boyle PD (2009) Genetic Characterization and Linkage Mapping of Barley Net Blotch Resistance Genes. Retrieved from http://scholar. lib.vt.edu/theses/available/etd-05262009-113923/

Oğuz AÇ, Karakaya A (2017) Pathotypes of Pyrenophora teres on barley in Turkey. Phytopathol Mediterr 56(2):224-234. https:// doi.org/10.14601/Phytopathol

Peakall R, Smouse PE (2006) genalex 6: genetic analysis in Excel. Population genetic software for teaching and research. Mole Ecol Notes2 6(1):288-295. https://doi.org/10.1111/j.1471-8286.2005. 01155.x

Peakall R, Smouse PE (2012) GenAlEx 6.5: genetic analysis in Excel. Population genetic software for teaching and researchan update. Bioinformat2 28(19):2537-2539. https://doi.org/10. 1093/bioinformatics/bts460

Peever TL, Milgroom MG (1994) Genetic structure of Pyrenophora teres populations determined with random amplified polymorphic DNA markers. Can J Bot 72(7):915-923. https://doi.org/10.1139/ b94-116

Peltonen S, Jalli M, Kammiovirta K, Karjalainen R (1996) Genetic variation in Drechslera teres populations as indicated by RAPD markers. Ann App Biol 128(3):465-477. https://doi.org/10.1111/j. 1744-7348.1996.tb07107.x

Rau D, Brown AH, Brubaker CL, Attene G, Balmas V, Saba E, Papa R (2003) Population genetic structure of Pyrenophora teres 
Drechs. the causal agent of net blotch in Sardinian landraces of barley (Hordeum vulgare L.). Theoreti App Genet 106(5):947959. https://doi.org/10.1007/s00122-002-1173-0

Richardson MJ (1990) An annotated list of seed-borne diseases, 4th edn. International Seed Testing Association, Zürich

Richter K, Schondelmaier J, Jung C (1998) Mapping of quantitative trait loci affecting Drechslera teres resistance in barley with molecular markers. Theor Appl Genet 97(8):1225-1234. https:// doi.org/10.1007/s001220051014

Schaller CW (1955) Inheritance of resistance to net blotch of barley. Phytopathology 45:174-176

Selim A, Omar A, Desouki S, Mohamed L (1973) Inheritance of mature plant reaction to net blotch disease of barley. Poljoprivz 22:64-70

Serenius M, Manninen O, Wallwork H, Williams K (2007) Genetic differentiation in Pyrenophora teres populations measured with AFLP markers. Mycol Res 111(2):213-223. https://doi.org/10. 1016/j.mycres.2006.11.009

Serenius M, Mironenko N, Manninen O (2005) Genetic variation, occurrence of mating types and different forms of Pyrenophora teres causing net blotch of barley in Finland. Mycologic Res2 109(7):809817. https://doi.org/10.1017/S0953756205002856

Smedegård-Petersen, V (1971) Pyrenophora teres f. maculata f. nov. and Pyrenophora teres f. teres on barley in Denmark. Yearb. R. Vet. Agric. Univ. pp 124-144.

Smedegard-Petersen V (1978) Genetics of heterothallism in Pyrenophora graminea and $P$. teres. Transact British Mycologic Soc 70(1):99-102. https://doi.org/10.1016/s0007-1536(78) 80177-6

Stefansson TS, Hallsson JH (2011) Analysis of the species diversity of leaf pathogens in Icelandic Barley fields. Icel Agric Sci 24(1):13-22
Stefansson TS, Serenius M, Hallsson JHJH (2012) The genetic diversity of Icelandic populations of two barley leaf pathogens, Rhynchosporium commune and Pyrenophora teres. Eur J Plant Pathol 134(1):167-180. https://doi.org/10.1007/s10658-012-9974-8

Steffenson BJ, Webster R (1992) Pathotype diversity of Pyrenophora teres f. teres on Barley. Phytopathol. https://doi.org/10.1023/A: 1002996722383

Steffenson BJ, Webster RK, Jackson LP (1991) Reduction in yield loss using incomplete resistance to Pyrenophora teres f. teres in barley. Plant Breed 75(1):96-100

Tekauz A (1985) A Numerical Scale to Classify Reactions of Barley to Pyrenophora teres. Can J Plant Path 7(2):181-183. https://doi. org/10.1080/07060668509501499

Tekauz A (1990) Characterization and distribution of pathogenic variation in Pyrenophora teres $\mathrm{f}$. teres and $P$. teres $\mathrm{f}$. maculata from western Canada. Can J Plant Path 12:141-148

Tóth B, Csosz M, Kopahnke D, Varga J (2008) First report on Pyrenophora teres causing lesions of wheat leaves in Hungary. Plant Pathol 57(2):385. https://doi.org/10.1111/j.1365-3059.2007. 01746.x

Ullrich SE (2011) Barley: Production, Improvement, and Uses. Wiley-Blackwell

Wallwork H, Butt M, Capio E (2016) Pathogen diversity and screening for minor gene resistance to Pyrenophora teres f. teres in barley and its use for plant breeding. Australas Plant Pathol 45(5):527531. https://doi.org/10.1007/s13313-016-0433-4

Publisher's Note Springer Nature remains neutral with regard to jurisdictional claims in published maps and institutional affiliations. 